\title{
Images of madness in the films of Walt Disney
}

\author{
Allan Beveridge
}

It has been demonstrated that images of madness in the media powerfully influence the general public and serve to perpetuate popular stereotypes of mental illness (Philo et al, 1993). While the cinema's treatment of psychiatric issues has received critical attention (Gabard \& Gabard, 1987), there is one area of film-making that has, so far, been neglected: the work of Walt Disney. Perhaps, because it has been primarily regarded as entertainment for children, Disney's work has not been subjected to serious examination. This neglect, however, is surprising in view of the current debate about the influence of the media on children. When one also considers that Disney films are now available on video and are being seen by millions, it seems worthwhile to look at the images of madness they present.

Disney has himself been the subject of a recent biography (Eliot, 1994), which has debunked the image of kindly 'Uncle Walt' and replaced it with a picture of an authoritarian taskmaster who was virulently anti-Semitic and anti-Communist; a troubled man, prone to heavy drinking and bouts of depression, who felt that he had been separated from his 'real' parents at birth and who spent much of his adult life trying to find them. His films have been interpreted as portraying the idealised happy family that he never had. While Disney's work has been related to his own troubled psyche, his treatment of the mental problems of his characters has not been examined.

\section{The films}

It is striking how often the theme of madness appears in the work of Disney. In an early film, Dumbo (1941), the hero's mother is locked up because she is a 'mad elephant'. She has been judged to be mad by the other circus performers because of a violent outburst in which she tried to protect her son from the taunts of the audience. The viewer realises that Mrs Jumbo is not mad and that she has been unfairly judged by others. Her behaviour, which seemed wild and uncontrollable, is actually quite understandable, and even commendable, in that she was trying to help her son. The community which has judged her is seen to be deeply unattractive: malicious, gossipy elephants, jeering little boys, an ineffectual ringmaster and drunken clowns. To be excluded from this society would almost seem to be an achievement, a sign of personal integrity.

Thus Disney's portrayal of madness in this film is really quite complex. It is a condition that needs segregating and shutting away from society, but society, itself, is shown to be rather suspect. And, in another twist, the subject who has been labelled crazy is not, in fact, mad. This, we will see, is a common device in Disney and we will see it being used again in other films: the hero is initially vilified or ridiculed for being mad, but is actually sane and triumphantly confirms his or her sanity at the end of the story. Thus Mrs Jumbo is freed from her cage and is reunited with her son.

Dumbo, himself, is briefly considered to have lost touch with reality and to have developed delusions that he can fly, but, of course, he proves his detractors wrong in a glorious finale by soaring over them. Interestingly, Dumbo's discovery that he can fly emerges after he has undergone an hallucinatory experience, an alcohol-induced bout of delirium tremens in which he sees pink elephants. Thus temporary insanity is portrayed as leading to self-knowledge and the revelation of hidden talents.

In a much later film. Beauty and the Beast (1992), the tension between the individual and society is also explored. The heroine, Belle is introduced to us at the beginning of the film as possibly mad, at least in the eyes of her community. As she strolls through her village. the people comment that she is "odd", "strange", "a funny girl". "so peculiar" and even that she is "crazy". She is perceived to be mentally suspect by the villagers because she is not like them - "so different from the rest of us". Her 'symptoms' are her bookishness, her day-dreaming, her yearning to escape the provincial, her aloofness, and her lack of interest in the local pin-up. Gaston. As in Dumbo, the society that sits in judgement of its misfits is seen to be very unappealing: the villagers are dull, stupid, uncultured, parochial, vain and superficial.

If the villagers are perplexed by Belle, they are quite sure as to the diagnosis of her father: he is a "crazy old loon". "Everybody knows that he is 
crazy", observes Gaston authoritatively. In the portrayal of Belle's father, we meet that popular stereotype - the mad inventor. And yet, the film suggests that he is not really crazy; his eccentric inventions are seen to work, and Belle is vindicated in defending him as a genius not a madman.

However, in the course of the film, Belle's father has to undergo a trial of his sanity by the villagers who charge him with "raving like a lunatic". His statement that he has seen the Beast is treated with contemptuous ridicule by the locals, who encourage him to repeat his claims for their own amusement. As the viewer knows, Belle's father is telling the truth and is therefore not mad. Once again, it is the community which is seen to be misguided.

This episode also introduces us to the maddoctor, possibly Disney's only animated representation of a psychiatrist. For those working in the mental health field the representation is not encouraging. He first appears in a darkened room at midnight where he sits conspiratorially with Gaston, plotting the wrongful confinement of Belle's father. He is a sinister-looking specimen, old and ugly with long, lank hair and bony fingers; he cackles maliciously. In exchange for gold from Gaston, he is quite prepared to lock Belle's father in his asylum, despite the fact that he regards him as harmless. Worse, although he finds Gaston's request "despicable", he observes with relish that he "loves it". Later, we see that the psychiatrist is also equipped with a special lunacy van with which he carts off his victims to the madhouse. Once again madness is seen as something that needs to be confined and locked away from the rest of us. And once again our hero is not really mad so that we can all breathe a sigh of relief.

In Mary Poppins (1964), which was loosely based on the novels of P. L. Travers, the paterfamilias, Mr Banks, is suspected of having a nervous breakdown when he starts to behave uncharacteristically. He is sacked from the bank. and this hitherto rigid and ultra-respectable Edwardian gentleman becomes irreverent, demonstrative and fun-loving. His employers at the bank conclude that "the man's gone mad" and call for the guards to take him away. Even his domestic staff question his sanity. One of them observes, "He's gone off his crumpet, he's as dotty as you please".

Mr Banks' apparent insanity manifests itself in his dishevelled clothes, his buoyant spirits, his singing and dancing, and by his display of affection. Banks' behaviour is seen as overturning bourgeois convention, portrayed as stiff, overly formal, humourless and repressed. Banks' personal crisis is ultimately self-enlightening: he has discovered the child in himself, symbolised by mending his children's kite. He changes from a remote and censorious patriarch to a warm and humane father who is at last able to communicate with his children.

His madness could be viewed in Laingian terms as a voyage of self-discovery: except, of course. like all Disney heroes, he is not actually mad. Once again he has been labelled mad by his community, in this case by Edwardian English society, whose ruling class is pictured as emotionally crippled. So does the hero's mental transformation lead to his rejection of bourgeois values? Not a bit of it - this is a Disney film, after all. Instead he gets his job back at the bank and lives happily ever after.

If thus far, Disney's mad characters are found on closer examination to be quite sane, there is one film in which the mad are definitely mad. This is Disney's 1951 adaptation of Lewis Carroll's Alice in Wonderland, for which Aldous Huxley provided part of the screenplay. As the Cheshire Cat informs Alice during her foray into Wonderland, "most everyone's mad here". In depicting the madness of the Cheshire Cat, Disney shows him to be slippery, elusive and contradictory; and, in fact, the film makes a visual pun out of the notion that he is "not all there" by having the Cat gradually evaporate into thin air. Alice, who is evidently the only sane one in the place, states that she does not want to go "amongst mad people" because they are "too easy to upset". Her views are confirmed when she attends the Mad Hatter's Tea Party. Here the mad are portrayed as perverse, violent and impossible to talk to. They spout "silly nonsense" and Alice concludes that it is the "stupidest tea party" she has ever attended.

Of course Disney's representation of madness in this film is based on Lewis Carroll's original story and it is true that the book equates madness with all things nonsensical. To this, however, Disney adds more violence and he downplays the mad characters' game with language and logic. Madness is portrayed as a kind of slapstick. Further, because the story is being rendered in a visual medium instead of on the printed page, it is not the verbal dexterity of the mad characters that impresses; rather it is their anarchic and violent behaviour which makes most impact on the viewer.

\section{Conclusion}

Disney disliked attempts to interpret his films and he apparently hated psychiatry, seeing it as a Jewish-Marxist conspiracy. However, his work contains many images of madness and, given the enormous audience that his films now reach, his art plays a major role in the creation and transmission of popular stereotypes of insanity. We have seen that madness is generally presented as something to fear and something that 
needs to be shut away. Disney's heroes hover over this frightening abyss but never fall into it; at the end of the day their essential sanity is vindicated. Disney seems to be saying that madness is a label that society uses when confronted with behaviour that it cannot understand; a view which puts him in the company of radical critics of psychiatry such as R. D. Laing and Thomas Szasz - strange company indeed for a fervent MacArthyite and anti-libertarian.

In Disney we can discern the perpetuation of the stock image of madness as a dangerous condition that needs confinement, but we are also, rather surprisingly, presented with the implication that society also colludes in the labelling and exclusion of those elements that it finds threatening or mystifying. Nevertheless, it is perhaps the image of mental illness as a violent state in need of chains and manacles that stays with the viewer - especially if he or she is a child - rather than the more subtle idea that it is something that society should try to understand.

It is difficult to trace any real development in Disney's rendition of madness over the decades, and this contrasts sharply with the great change that has occurred in his portrayal of women. The simpering Snow White, dutifully going about her household tasks, while she waits for her prince to come, has been replaced by the more dynamic Belle who reads books, fights with wolves and makes up her own mind about prospective suitors. It would be encouraging if future Disney films witnessed a similar transformation in the image of the mentally ill.

\section{References}

Euor, M. (1994) Walt Disney. London: André Deutsch. GABARD, K. \& GABARD, G. (1987) Psychiatry and the Cinema Chicago: University of Chicago Press.

Philo, G., Henderson, L. \& MCLaughin, G. (1993) Mass Media Representations of Mental Health/Iliness. Glasgow Media Group. Glasgow: Glasgow University Publications.

Allan Beveridge, Consultant Psychiatrist, Queen Margaret Hospital, Whitefield Road, Dunfermline, Fife KY12 OSU 